\title{
The Myth of Defending the Homeland \\ Combat Preparation in Conscripts' Reflections of Compulsory Military Service (1968-2004)
}

\section{Jiří Hlaváček}

Institute of Contemporary History, Czech Academy of Sciences, Prague

Since the late eighteenth century, compulsory military service has been one of the important mechanisms in the functioning of modern nation states in Europe, through which the ruling power has aimed to discipline, indoctrinate, socialize but, above all, to mobilize its citizens for the defence of the territory and the existing social order, in the event of a threat to state sovereignty.

The French notion of a nation-in-arms was in this respect not an entirely new idea as this was a militia system that had dominated Western society from the time of ancient Greece until the Middle Ages (as opposed to tribal warfare). This system reserved the status of warrior only for specific sections of the population: either those who came from the highest social strata (landowners, aristocracy) or those who ranked the lowest in the social hierarchy (mercenaries, convicts). It was only military conscription under the conditions of the modern state after the French Revolution that gave every man the possibility to make the highest possible sacrifice ("to lay down his life for his country") if necessary, establishing therefore an imaginary equality and becoming, on the one hand, a symbol of civil liberties and, on the other, a sort of general price for these newly acquired liberties. ${ }^{1}$

Despite its first occurrence in France, fully fledged military conscription was successfully implemented for the first time in Prussia nearly a century later, where it included an elaborate system of reserves and their mobilization. Due to its popularity after the Prussian victories in the wars of 1866 and 1870, compulsory military conscription spread to a number of other European countries, including

\footnotetext{
1 See KEEGAN, John: A History of Warfare. London, Hutchinson 1993; HARARI, Yuval Noah: The Ultimate Experience: Battlefield Revelations and the Making of Modern War Culture, 1450-2000. London, Palgrave Macmillan 2008.
} 
the Austro-Hungarian Empire. ${ }^{2}$ Prussian "statism" was based on the premise that the purpose of the state was to accumulate power, maintain it and use it, either inward (against its own citizens) or outward (against an external enemy). The emergence, survival and development of a state was in the context of the period conditioned by its capacity to win wars, which also served as evidence of its high moral value. This capacity was manifested outward not only through its international policy, but mainly by the existence of a strong and disciplined army. ${ }^{3}$

In the Bohemian lands, compulsory military conscription was introduced in 1868, and its format saw only partial changes in the following century. After the First World War and the creation of independent Czechoslovakia, compulsory military service was regulated by the Conscription Act approved in March 1920, which set the period of service at 14 months. In the following decade, the period of service changed several times until it was fixed at two years in 1934. This provision remained unchanged in the conscription laws until the early 1990s. Even though the new army of the First Republic was built on democratic principles following the French model (i.e. it was put under the civil control of parliament), little changed in terms of the everyday life of the army, since a major part of the principles was taken over from the previous period of the Austro-Hungarian army. After February 1948, for more than four decades, the Czechoslovak army was built exclusively following the socialist model, with the emphasis on a high degree of ideologization and absolute subordination to the defence needs of the Soviet Union. Until 1989, the military service was the "patriotic" duty of almost every man in Czechoslovakia. After the fall of communism, compulsory military service was shortened several times. First, in 1990, when it was shortened from two years to 18 months. Three years later, it was set at only one year, together with the possibility of doing substitute civilian service, which was, however, only half as long. One year of compulsory military service was confirmed for the last time by the Conscription Act of 1999, but it was abolished only five years later, and in January 2005, the Army of the Czech Republic became fully professional.

During the entire existence of compulsory military service, the Czech public's attitude to it was deeply ambivalent. On the one hand, it represented a certain form of individual deprivation (popularly described as "a drag"). On the other hand, however, to have done one's military service was seen as an important proof

\footnotetext{
2 SOUTOU, Georges Henri: Europäische Militärgeschichte vom Beginn des 19. Jahrhunderts bis zum Ende des Kaltes Krieges. In: ECHTERNKAMP, Jörg - MACK, Hans-Hubertus (eds.): Geschichte ohne Grenzen? Europäische Dimensionen der Militärgeschichte vom 19. Jahrhundert bis heute. Oldenburg, De Gruyter 2016, pp. 27-38, here p. 29.

3 MALESEVIC, Sinisa: The Sociology of War and Violence. Cambridge, Cambridge University Press 2010, pp. 29-33.
} 
of masculinity and manhood, as is reflected in the popular saying that "military service makes boys into men". The importance of this institution for both the individual (a rite of transition) and for society (education to citizenship) therefore represents an interesting subject of interdisciplinary research, which may be viewed from different perspectives and in terms of different structural and functional relations. Moreover, it is a relatively topical issue, as less than two decades from its abolition, the phenomenon of compulsory military service is gradually disappearing from most personal and collective identities, and its actors are becoming, in the true sense of the term, contemporary witnesses.

Surprisingly, however, the issue has not received much attention in Czech historiography. The only interest shown has been in the form of several factually-oriented studies and monographs, but these are limited in terms of time and themes. They tended to focus rather on the organizational structure of the army before 1989 and on specific events in the "big" history (such as the occupation of Czechoslovakia in August 1968 and the Velvet Revolution in November 1989). ${ }^{4}$ Military research in the field of cultural and social history, targeting the reflections of ordinary soldiers (as opposed to professional soldiers) is largely missing. The situation abroad is, however, very similar. Among the former states of the Eastern Bloc, selected aspects of compulsory military service have been analysed only in Russia, Germany and Poland. These research works focus on the relations between conscripts, or rather the issue of unofficial disciplinary order and its pathological manifestations (i.e. hazing between the different groups of conscripts based on the year of their conscription). ${ }^{5}$ Therefore, an attempt at

4 See BÍLEK, Jiří - LÁNÍK, Jaroslav - MINAŘíK, Pavel - POVOLNÝ, Daniel - ŠACH, Jan: Československá lidová armáda v koaličních vazbách Varšavské smlouvy (květen 1955 - srpen 1968) [The Czechoslovak People's Army in the Coalition Relations of the Warsaw Pact (May 1955 August 1968)]. Praha, Ministerstvo obrany ČR 2008; POVOLNÝ, Daniel: Operace Dunaj: Krvavá odpověd' Varšavské smlouvy na pražské jaro 1968 [Operation Danube: The Bloody Response of the Warsaw Pact to the Prague Spring in 1968]. Praha, Academia 2018; IDEM: Nejhorši den Československé lidové armády: 21. srpen 1968 [The Worst Day of the Czechoslovak People's Army: 21 August 1968]. Praha, Academia 2020; TOMEK, Prokop: Československá armáda v čase sametové revoluce: Proměny ozbrojených sil na přelomu osmdesátých a devadesátých let [The Czechoslovak People's Army During the Velvet Revolution: Changes in the Armed Forces in the Late 1980s and Early 1990s]. Cheb, Svět křídel 2019; KOLDINSKÁ, Marie - ŠEDIVÝ, Ivan: Válka a armáda v českých dějinách: Sociohistorické črty [War and Army in Czech History: Sociohistorical Studies]. Praha, Nakladatelství Lidové noviny 2008; HLAVÁČEK, Jiř́i: Vzestup a pád ČSLA? Vojenská profese v kolektivní paméti důstojnického sboru (1960-1970) [The Rise and Fall of the Czechoslovak People's Army? The Military Profession in the Collective Memory of the Officer Corps (1960-1970)]. Praha, Karolinum 2020.

5 See, for example, HERSPRING, Dale R.: Dedovshchina in the Russian Army: The Problem that Won't Go Away. In: Journal of Slavic Military Studies, Vol. 18, No. 4 (2005), pp. 607-629; 
a comprehensive Central European (or East European) comparison of compulsory military service from the end of the Second World War to the present time is still lacking in local and foreign historiography.

The situation is quite different in the United States, where - given the frequent deployment of American soldiers in direct combat in the past century (i.e. the Korean War, the Vietnam War, Persian Gulf, Iraq, Afghanistan) - numerous researchers are dealing not only with the factual and organizational history of the army, but also with the social, cultural and ethical aspects of military service. However, once again, these are concerned mostly with the experiences of the professional (albeit rank-and-file) soldiers, not conscripts. ${ }^{6}$ Similar studies describing the actors' reflections of combat experience after 1945 can, of course, also be found in Western Europe. ${ }^{7}$

Theoretical-Methodological Base

This study seeks to capture one of the functional aspects of compulsory military service, which is preparation for combat (or defence of the homeland). This is done using the narrative analysis of representations, through which contemporary witnesses (from various generations) consciously or unconsciously (re)construct and articulate memories of their military service. I draw on 100 interviews carried out within a grant project which was implemented in 2019-2021 by two institutes of the Czech Academy of Sciences (the Institute of Contemporary History as the principal investigator and the Institute of Ethnology). All the interviews cited in this article were conducted in line with the established methodological

RADKOWSKI, Rafał: „Fala“ a „postfala“: Ceremoniat subkultury żotnierzy wobec zmian w Wojsku Polskim na przetomie XX i XXI wieku. Warszawa, Wydawnictwo JM 2019; MÜLLER, Christian Thomas: Die „EK-Bewegung“ in den Kasernen der NVA: Eine Form von „sekundärer Anpassung“ in „totalen Institutionen“. In: EHLERT, Hans - ROGG, Matthias (eds.): Militär, Staat und Gesellschaft in der DDR: Forschungsfelder, Ergebnisse, Perspektiven. Berlin, Ch. Links 2004, pp. 559-583; SMITH, Tom: Comrades in Arms: Military Masculinities in Eastern German Culture. New York - Oxford, Berghahn 2020.

6 See, for example, AXINN, Sidney: A Moral Military. Philadelphia, Temple University Press 2009; HOLMES, Richard: Acts of War: The Behaviour of Men in Battle. New York, The Free Press 1986; KOONTZ, Christopher N. (ed.): Enduring Voices: Oral Histories of the U. S. Army Experience in Afghanistan, 2003-2005. Washington, D.C., Centre of Military History US 2008; MIRRA, Carl: Soldiers and Citizens: An Oral History of Operation Iraqi Freedom from the Battlefield to the Pentagon. New York, Palgrave 2008.

7 See, for example, ALEXANDER, Martin S. - EVANS, Martin - KEIGER, J. F. V.: The Algerian War and the French Army, 1954-1962: Experiences, Images, Testimonies. New York, Palgrave 2002; McMANNERS, Hugh: Forgotten Voices of the Falklands. London, Ebury Press 2008. 
and ethical standards of oral history, which aims to broaden our knowledge of the past by analysing and interpreting the recollections of contemporary witnesses. ${ }^{8}$ The respondents (exclusively men) were selected based on a combination of an open call, a targeted selection and a random sampling, so that they would evenly cover not only the time period of this research across individual decades (i.e. between 1968 and 2004), but also the different branches of the then Czechoslovak/Czech army (ground forces, air forces, air defence), including ordinary, specialized as well as elite types of the specific army units. The last important criterion in sampling was the educational level of the witnesses at the time of conscription, which governed the length of service (one or two years) until 1989.

From the methodological point of view, every interview was audio-recorded. Interviews were typically conducted in one meeting and divided into two parts. In the first, narrative part, the witnesses were asked to freely recollect the course of their military service. There was no time limit and the interviewer did not interrupt the narration. Once the respondent had finished the free recollection, the interview gradually moved to the second part, in which the witnesses were asked open questions in three predetermined thematic areas, focusing on reflections on temporality, everydayness and the meaning of military service. The way the questions were asked and their order were adapted individually to each witness, based on the previous narrative part of the interview and information obtained in it. ${ }^{9}$

The oral history sources were then anonymized and analysed using the methods of autobiographical and episodic (sequential) narrative analysis, anchored in the paradigm of social constructivism. ${ }^{10}$ The narrative is understood as a discourse with a clear sequential order, which links individual events into meaningful units, intended for a certain audience (in this case a potential interviewer or reader), and it therefore offers an insight into understanding the way the specific contemporary witness (re)constructs social reality. ${ }^{11}$ Discursive construction

\footnotetext{
8 See ABRAMS, Lynn: Oral History Theory. New York, Routledge 2010.

9 The interviews each took an average of 90 minutes. The audio recordings of interviews, transcripts and reports are stored in Rozhovory, Digitální sbírky Centra orální historie Ústavu pro soudobé dějiny AV ČR [Interviews, Digital Collections of the Oral History Centre at the Institute of Contemporary History of the Czech Academy of Sciences] (hereafter Rozhovory, DS COH ÚSD) and will be made available to the public in accordance with the research order and provisions of the informed consent of particular contemporary witnesses. More detailed information is available on the website of the Oral History Centre: www.coh.usd.cas.cz.

${ }^{10}$ BERGER, Peter L. - LUCKMANN, Thomas: The Social Construction of Reality: A Treatise in the Sociology of Knowledge. New York, Anchor Books 1966.

${ }^{11}$ HINCHMAN, Lewis P. - HINCHMAN, Sandra K.: Memory, Identity, Community: The Idea of Narrative in the Human Science. New York, SUNY Press 1997, p. 16.
} 
takes the form of a narrative, the coherent content of which is organized by formally structuring the storyline around a beginning, a middle and an end. ${ }^{12}$ In analysing the data, I mainly paid attention to three basic semantic levels of narration: the content (the story), the form (the structure of the narrative) and the interactive context (the relation between the narrator and interviewer). On all three levels, the (individual and collective) identity of the witnesses, which is always of a narrative character, is manifested in a certain way. ${ }^{13}$ In this respect, the narration on compulsory military service may be understood as an idealtypical example of a clearly delineated episodic narrative, which in many cases has an identity-forming character.

On a theoretical level, I openly subscribe to the research concept of new military history, drawing inspiration in particular from a cultural model of military history. The author of this model, the American historian John A. Lynn, explores the changing relation between the official, normative model (i.e. the ideal-typical discourse on war, army and military service) and the actors' practice (i.e. the lived reality).${ }^{14}$ The representation of compulsory military service should therefore be understood as the result of a process of interaction, confrontation and competition between the three discourses, which, under certain circumstances, may be seen to overlap to some extent and therefore allow for the individual meanings to fluctuate. Whereas the official discourse concentrates itself on the ruling power's ideas about what military service should ideally look like, the actors' discourse offers the experience of those who have actually experienced military service, providing therefore a certain corrective to the official norms.

The actors come to the army with certain expectations that are formed by the official discourse and developed by the public discourse. After having served in the army, they return to society, where, based on their individual experience, they rectify (i.e. confirm, develop, but mostly dispute) the majority representation of compulsory military service, or produce new categories of meanings (for example, military service as a "waste of time", a "drag", a "discovery of something new" or "meeting the unknown"), which can usually, however (given the more than a century-old tradition of this institution in the Bohemian/Czech lands), be linked to the already existing meanings (that is, discipline, socializing and initiation).

A specific role is then played by the public discourse, which not only creates a space for negotiation between the official ideas and actors' experiences, but

\footnotetext{
${ }^{12}$ HAMAR, Eleonora: Vyprávěná židovství: O narativní konstrukci druhogeneračních židovských identit [Narrated Judaisms: On Narrative Construction of Second-Generation Jewish Identities]. Praha, Sociologické nakladatelství 2008, p. 17.

${ }^{13}$ RICCEUR, Paul: Temps et récit, Vol. 3: Le Temps raconté. Paris, Seuil 1985, p. 100.

${ }^{14}$ LYNN, John A.: Battle: A History of Combat and Culture. New York, Basic Books 2003.
} 
also offers its own historical, as well as contemporary, collectively and culturally shared representations of compulsory military service, including pop-culture images and their reflections (in fiction, music, films, television series, etc.).

\section{Compulsory Military Service as Preparation for the Defence of the Homeland?}

The basic mission of any army is to defend the territory against an external threat. This is also what the original meaning of the word voják [soldier in Czech] - one of the $v o j$ (that is an army troop, a squad pursuing the enemy) - makes an etymological reference to. A soldier is an armed individual who goes to war (vojna) when necessary to repel the enemy and to win the military confrontation..$^{15}$ This is also why, since the beginning of modern history, the armed forces have been considered one of the symbols of sovereignty and a guarantee of the existence of nation states. It is therefore not surprising that, in the context of the Czechoslovak and later the Czech armed forces, the collocation "defence of the homeland" is one of the most frequently used in official norms of the period. ${ }^{16}$

The main task of an army is to fight, and when it does not, it should at least be preparing to do so. It is therefore an institution which, throughout its modern existence, must cope historically and culturally with the immanently present and absurd fact that as an instrument of impersonalized killing, legalized and generously sponsored by the state, it trains troops for decades, waiting for its moment of action - a moment which nobody knows when to expect, what it will eventually look like and indeed whether it will come at all. Since periods of peace clearly prevail over the periods of war in the history of humanity, most of the time soldiers generally do not have the opportunity to prove their social usefulness in any other way than by making reference to the preventive role of the army (si vis pacem, para bellum).

However, in the case of the Czechoslovak army, this way of legitimization is greatly complicated by the historical and political development of the Bohemian/ Czech lands after 1918, which may be characterized by the absence of any direct deployment of the army, or rather its defeatism, albeit politically determined (mobilization in September 1938 and invasion in August 1968). After 1968, the significance of the Czechoslovak People’s Army (Československá lidová armáda - ČSLA)

\footnotetext{
${ }_{15}$ MACHEK, Václav: Etymologický slovník jazyka českého [Etymological Dictionary of the Czech Language]. Praha, Academia 1968, p. 696.

${ }^{16}$ See, for example, Collective of authors: Vojenský terminologický slovník [Dictionary of Military Terms]. Praha, Naše vojsko 1966, p. 312.
} 
as a guarantor of national sovereignty was a mere illusion, given the total subordination of military and security matters to the Warsaw Pact (or rather to the Soviet Union) and the permanent deployment of the Soviet army in Czechoslovak territory. In November 1989 - in the case of the Velvet Revolution initiated from below by students - the Army was again perceived as an obstacle rather than an instrument to freedom. However, even during the normalization era, at the level of public discourse the primary role of conscripts was to defend the homeland from the threat of an imperialist enemy. This was to be achieved mainly by maintaining the permanent combat readiness and the high combat effectiveness of the army. ${ }^{17}$ Most of the witnesses therefore logically expected before the draft that once in the army they would engage intensively in military training that would prepare them adequately for "the activity which aims to eliminate the enemy physically and deprive them of their capacity to resist". ${ }^{18}$

Throughout communist rule, the enemy was, from an ideological perspective, clearly defined and forever implacable. On a general level, this was embodied by the imperialist armies of the United Stated of America and NATO, and, more specifically, it was the West German army (Bundeswehr) with which the first clash was expected in the case of an armed conflict. In this context, what should be recalled is the widespread heterostereotype of the German nation as a historically hereditary enemy of the Bohemian/Czech lands, which, before 1989, was still deeply rooted in the cultural consciousness of some of the witnesses: "The army [in the first half of the 1980s] was something completely different, in a much worse state than in 1938. Back then, people still had patriotic feelings and national pride. We had none of this anymore, (...) if anything started, I would surrender to the first American, Brit or Frenchman (...) not to the Western Germans, my national pride (...) wouldn't allow me to do that. I wouldn't surrender to a Fritz, but to the others straight away, and if some brass hat wanted to stop me, I would spray bullets into him, without any problems." 19

Nevertheless, according to the recollections of the vast majority of witnesses, the official image of the enemy as imperialist warmongers was nothing but ideological rhetoric in the 1970s and 1980s, and in fact nobody expected that a classic conventional war would take place. Even a brief rise in international tension during the Euromissiles Crisis in the early 1980s (i.e., the issue of the deployment

\footnotetext{
${ }^{17}$ VALEŠ, Jan - VESELÝ, Mirko: Základní řády: ̌̌ád vnitřní služby ozbrojených sil ČSSR [Basic Regulations: Regulation of the Internal Service of the Armed Forces of the Czechoslovak Socialist Republic]. Praha, Státní pedagogické nakladatelství 1980, p. 138.

${ }^{18}$ Collective of authors: Vojenský terminologický slovník, p. 22.

${ }^{19}$ Interview with Z. N., conducted by Kateřina Niekurzáková, 4 January 2020. Rozhovory, DS COH ÚSD.
} 
of SS-20 Soviet missiles and American Pershing II missiles) brought little change to this approach. The word "enemy" is therefore virtually absent in the recorded interviews. In this context, the army found itself in an even more curious situation after the disintegration of the Soviet Union and the disbanding of the Warsaw Pact in the early 1990s, when, after more than 40 years, suddenly there was no immediate enemy nor a clear definition of the enemy. This factor is also reflected in social debates on the "anachronism" of this institution in the democratic conditions, which accompanied the army at least until 1999, when it was incorporated into NATO structures. ${ }^{20}$ The new image of an enemy and the potential threat of conflict reappeared clearly in the official discourse only after the terrorist attacks on the World Trade Centre in New York on 11 September 2001. This is also reflected by some of the contemporary witnesses who did their military service in the last years of its existence before it was abolished.

From the actors' perspective, the narrative related to "real combat" (or the preparation for it) may be followed at several thematic levels: reflection on military exercises, relation to weapons and their possible use (guard duty), evaluation of combat vehicles and effectiveness of combat training alerts. However, the key element most influencing the retrospective positive or negative interpretation of these issues was always the type of armed forces (or specific army unit or troop) in which the witness in question served. Throughout the researched period, there was an unwritten hierarchy of prestige in the army reflecting the difficulty of training as well as the operation of trusted combat vehicles. At the head of the hierarchy were military units under the air forces, missile forces, air defence forces and airborne forces. These were followed by artillery, chemical units and sappers. The lowest ranks of the hierarchy were occupied by the tank units and primarily by cavalrymen (mechanized infantry). Border guard units, which became part of ČSLA as late as 1966, had a specific position among the units with regard to how close to real combat they were. The witnesses who served in the border guard units were probably the only conscripts before 1989 who were exposed to the real everyday possibility of using a weapon or physical violence during their military service, which also translated into a better climate in military groups in the border areas with regard to official as well unofficial disciplinary

\footnotetext{
${ }^{20}$ According to the opinion survey of $1991,55 \%$ of citizens believed that the real danger of a world war had not been averted yet. This was mainly due to the uncertain situation in the successor states of the former Soviet Union. However, in terms of ensuring the safety of the Czechoslovak territory, the concluding of corresponding international treaties and obligations $(70 \%)$ was seen by the public as more important than building a strong and operational army. See CVRČEK, Jaromír: Vzájemné vztahy společnosti a armády: Teoreticko-empirická studie [Relations Between the Society and Army: Theoretical-Empirical Study]. Praha, Správa sociálního řízení FMO 1992, p. 67.
} 
order. Border guards, like airborne, missile, air and air defence forces, belonged among the elite army units, where more emphasis was put on the selection and cadre profiles of the conscripts, but where - due to an increased risk of danger (the use of weapons, stress, accidents, the need to concentrate, etc.) - there was also a greater micro-solidarity (and hence a lower level of hazing). The worst situation with respect to interpersonal relations existed in the rear and school units, which until the disintegration of Czechoslovakia were mostly deployed in the territory of contemporary Slovakia and which were not to be deployed in the front line.

However, if we try to generalize the testimonies obtained, regardless of the kind of military units the narrators had served in, we will arrive at the (un)surprising conclusion that most of them were disillusioned with how little compulsory military service prepared them for "real combat" conditions. They were shocked at the state of the (People's as well as the post-November) army in terms of combat effectiveness. ${ }^{21}$

\section{Military Manoeuvres as Theatre Performances}

Contemporary witnesses emphasized the repetitive routine scenarios of pre-1989 military training exercises, which were always held in the same places. This converted the intended simulations of different combat situations into an automatized routine, which was only about improving the time and results of the shooting exercise: "When we did a training exercise, we looked for the familiar places, and when we were supposed to bury a vehicle we went to the very same places, and all the ditches would already be there, so we would always pull into one that was already prepared, it was all just play-acting." 22

The fact that similar military exercises were widespread during the normalization era is evidenced by the - officially sanctioned - criticism which appeared in the public discourse as early as the early 1980s: for example, in the Czechoslovak television series Velitel [Commander]. In one of the final episodes of this agitprop normalization-era opus, a young, politically conscious idealist, first lieutenant Lípa, is transferred to a new tank unit, whose combat readiness he finds

\footnotetext{
${ }^{21}$ A sociological survey among conscripts in 1997 came to a similar conclusion. The soldiers expected more from compulsory military service than it could actually offer them, especially in terms of training. However, surprisingly only $13 \%$ of them felt insufficiently prepared for actual combat. See HENDRYCH, Jiří: Voják v míru [Soldier in Peacetime]. Praha, Ministerstvo obrany ČR - AVIS 1998, p. 50.

${ }^{22}$ Interview with D. Š., conducted by Petr Wohlmuth, 7 November 2019. Rozhovory, DS COH ÚSD.
} 
"barely satisfactory" after the first military training exercise. With zeal, he tries to draw attention, both along official and political lines, to the inadequate state of the military vehicles, to the manipulation of the shooting results, and especially to the routine of tactical exercises (the plans and variability of which remained unchanged for several years). Due to his attitude, he comes into conflict not only with his superiors and colleagues, but also with the conscripts, who logically find the existing conditions convenient. ${ }^{23}$ If we go back to the interviewed witnesses, they also clearly found this routine convenient. However, there was also criticism, indicating that they were clearly aware that this kind of military training was only "playing soldiers", whereas real combat would be something very different: "Well, from time to time we did discuss whether we were or not in this way [prepared for a combat], how long we would survive - that if the statistics say that the lifetime of an infantryman is 22 seconds, and a tank about a minute and half, or something like that, I don't know how long the lads, or I, would survive in real combat, if real bullets started flying past our heads and shrapnel started falling among us. What would happen with us, would we run away or not? Nobody really knows that. There was a rumour that when they did this to graduates of the military college, when they crammed them into trenches where they only sat and machine guns were fired above them, the bullets whistling over them, that the majority ran away, they had an escape route somewhere, and most of them could not cope with it psychologically." ${ }^{24}$

Similar narrations were mostly typical for former conscripts who served in the cavalry and tank units, because it was these units which were to be deployed on the front line in the event of a future conflict (i.e. they were to be the imaginary cannon fodder) and - unlike the air forces, artillery, signals or sapper units - which were to be in direct contact with the enemy (whether face to face or within firing range of firearms or artillery). ${ }^{25}$ However, to come to any conclusions regarding the hypothetical behaviour of witnesses in a real battle based on similar recollections is difficult. As the British historian Richard Holmes notes,

${ }^{23}$ In one of the scenes, Lípa states at the regiment's staff meeting that "it is precisely the fourth time that the soldiers of the second year have done this exercise. They know the advance of every tank, every terrain obstacle, every molehill, every firing position, and all firing parameters by heart, and because they are not stupid, they have also discovered all the tricks to make the task easier, which is understandable." Obviously caught off guard, his superior gives him a swift, embarrassed answer that "only by constant repetition can the soldiers acquire all the necessary habits, in order to, kind of, succeed in combat!" See Velitel [Commander] (episode 5). Drama, Czechoslovakia 1981, directed by Zdeněk Kubeček.

${ }^{24}$ Interview with P. D., conducted by Petr Wohlmuth, 2 September 2020. Rozhovory, DS COH ÚSD.

${ }^{25}$ For example, a third of witnesses who had served in the signal forces admitted in the interviews that during field exercises throughout their compulsory military service they were 
in a combat situation, micro-solidarity at the unit level tends to prevail over the opinions, ideology or morale of individuals, resulting in a (greater) willingness to fight. ${ }^{26}$

After November 1989, however, even these staged "theatre performances" in the form of military exercises disappeared from the army's "repertoire". As a result of uncertainty regarding the future course of the army, its "slimming down", and the humanization of military service, combat activities were mostly replaced with never-ending duties of various kinds. More than three-quarters of the respondents who did their service under democracy, for example, did not reflect in the interviews any experience with leaving the barracks for the military training areas, whereas in the experience of conscripts in the socialist army, the incidence of this issue was just opposite. ${ }^{27}$

Similar conclusions were reached by the anthropologist Hana Červinková in her field research, conducted at an unnamed air base in 2001-2002. As she noted, instead of a tough test of manhood, full of physical exertion and hardship, which the conscripts had heard about from the previous generations of their fathers and grandfathers, what they often experienced as active soldiers was disillusion and the "killing" of time with pointless duties, which in addition mostly consisted of typically "women's chores" such as cleaning and cooking. This in effect raised feelings of emasculation among them. ${ }^{28}$ Similar narratives can also be found in the interviews in the last years of the existence of compulsory military service. They indicate mainly a feeling of distrust or more generally of the opposition of professional soldiers to providing the conscripts with modern technology for training.

In this case, we can also look at another type of source, which is an authentic diary entry of one of the narrators, who spent his first months of compulsory military service in the signals unit. With the benefit of two years of hindsight he added an international comparison, which is undeniably very valuable for the purposes of this study.

not able to establish radio contact without any complications and according to a given scenario. See Interview with L. Z., conducted by Jiří Hlaváček, 10 June 2019. Rozhovory, DS COH ÚSD.

${ }^{26}$ JANOWITZ, Morris - LITTLE, Roger: Sociology and the Military Establishment. New York, Russell Sage Foundation 1965, p. 12.

${ }^{27}$ UBS - univerzální bouchač služeb [universal duties performer - meaning dogsbody] became a popular slang abbreviation among the conscripts in the 1990s.

${ }^{28}$ ČERVINKOVÁ, Hana: Playing Soldiers in Bohemia: An Ethnography of NATO Membership. Praha, Roman Míšek - SET OUT 2006, p. 76. 
"The modern army is a matter of specialists. In the classic model of the Warsaw Pact, communications were a question of three specialists. The first specialist was the man who ran with a backpack laying cable under enemy machine gun and mortar fire and risked his life to allow his superiors to communicate with one another. The second specialist is the one who operates these devices. He has to know Morse Code and probably also know how to make calls. The third specialist is the one who understands these devices and can repair them. A hero with a screwdriver! A signals techie. This was supposed to be me and my entire platoon. The problem is that times change and we were no longer needed. When something breaks down, it only matters whether it is under guarantee or not. If it is, it's sent back under warranty. If not, it is thrown away. We live in a consumer capitalist society and the army keeps up with the times. We could learn how to repair some old machines (...) but it wasn't worth it. To teach us to fix (...) newer digital walkie-talkies? There were about two of them at the entire garrison and we were barely allowed to touch them (first wash your hands!), but certainly not to disassemble them and examine them. To get their diagrams? No, we didn't deserve that much confidence. So, during the course of two days I learnt how to connect a field telephone with the central exchange (...) and set up a folding antenna, quickly. It was not entirely uninteresting, but still it was rather limited knowledge. Unfortunately, I dedicated more of my time to washing dishes. Two years later, I visited similar installations in Switzerland. A friend of mine studied as a communications mechanic in the Swiss army, during compulsory military service like me. Should I compare them? There is no comparison: Armourplated notebooks, optical fibres, satellite communication... But the difference was not only about technology. They also learnt practical tasks, for example, how to ensure communication between artillery and reconnaissance to direct the fire. Their walkie-talkies were no better than ours (...) but they ran with them outside and included them in the drills. Nobody would let us do that. There is much talk of a professional army. It surely is a cheaper solution. But I would have no objections to a Swiss type of army, where even the conscripts are taken seriously, as pros..$^{29}$ I was aware that for the Czech army I was only an unqualified worker for cleaning, and I felt no guilt when I behaved accordingly."30

${ }^{29}$ In the context of compulsory military service, Switzerland represents an exception among European countries with its unique historical experience of neutrality. The Swiss army must therefore be understood as a form of civic militia, which is mainly to provide support to the civilian security forces (police, medical staff and fire brigades) in the event of necessity (extraordinary situations, natural disasters, threats to internal security, etc.), even though it tries to keep up with modern trends in terms of military equipment.

${ }^{30}$ J. H.: Scifista ve válce proti teroru [Sci-fi Fan in the War Against Terror]. A narrator's diary (ego-document, unpublished) 2002-2003, p. 8. In this context, it should be noted that the 


\section{Compulsory Military Service as the (First) Experience with Weapons}

In the memory of many actors (with the possible exception of those who served in the paratrooper forces or in similarly specialized units), real "combat training" is therefore limited only to the period of intensive basic training (so-called prijimač), which they received immediately after the draft for a period of one month, and which included (for many of them) their first experience with firearms. Weapons, as instruments with a harmful effect for enforcing one's interests, have been associated with the institution of the army since its very beginnings. The word "army" is historically derived from the Latin word arma, which translates as "weapon". ${ }^{31}$ Furthermore, international law usually defines a soldier as an armed person in a military uniform. The weapon and uniform are therefore the most common attributes of army members throughout the world, and compulsory military service was - especially in the case of state socialism - also one of the few legal situations for carrying arms (except for members of the Czechoslovak Hunting Union, SVAZARM [Svaz pro spolupráci s armádou - Association for Cooperation with the Army] and Public and State Security).

The narrators therefore automatically assumed that they would get their hands on a firearm during their military service and learn how to use it. However, these expectations were only partially fulfilled, and the reflections of actors in this sense were more than disconcerted. Whereas, according to the witnesses, the attention paid to firearms training, learning how to handle them safely, how to assemble and disassemble them (sborka and rozborka) was almost draconian, with regard to shooting with live ammunition (and the state of weapons) it was much worse. ${ }^{32}$ Nearly three-quarters of the narrators shot only once or twice during their one

situation of this witness did not change even after he was transferred to the tank forces, as is shown by this excerpt from the interview: "I saw a tank like once, yeah? Given that I spent nine months in the tank battalion (...) it is quite surprising that I saw a tank once. All the others were simply in storage somewhere in the garages, where they were covered with grease for protection, but on the understanding that nothing would happen to them anyway." Interview with J. H., conducted by Jiř́i Hlaváček, 6 May 2019. Rozhovory, DS COH ÚSD.

${ }^{31}$ MACHEK, V.: Etymologický slovník jazyka českého, p. 38.

32 "I did not like the 58 [submachine gun model 58], because I always was a good shot but those we had in basic training, they were hell. Because, when you finally set everything so that it fired normally, then the shooting was over and you have already fired your live ammunition (...) and the next time I got a different one, of course. And mostly, as it is during this training, you bang it around, jump over concrete walls with it and so on, (...) then these guns simply do not shoot, it was impossible." Interview with P. J., conducted by Jiří Hlaváček, 12 April 2019. Rozhovory, DS COH ÚSD. 
or two years of compulsory military service, and the total use of live ammunition amounted on average to only five to ten rounds per person. This resulted in some absurd situations, especially in the case of those witnesses whose military expertise was as a "shot", as in the following case: "It [nine rounds] was divided in three sessions. And another funny thing was that in the first shooting practice three rounds were fired individually, in the second one there was a burst of fire, that is, one pull of the trigger fired three rounds. And then there was the third session, and that was three single rounds again. It was really bad."33

This was also why the staff at the firing ranges often enjoyed a privileged, or even untouchable position, because they had the opportunity to significantly influence the shooting results: "We, up there in the control room [of the firing range] had everything on, the lights and levers, and we knew who had to shoot what, so the brass hats came to us and tried to tell us that we must have a device. (...) But the fact is that we could change things, (...) so when I saw some soldier shoot and he was nice to me, and his superior didn't act like an idiot (...), so when I saw that they did not do very well, then I sent it [the targets] down. (...) So, it could actually be said that, as the staff of the firing range, we had a position as a kind of, or I had, I don't know, executioner. [laughs] (...) Because, if someone [officers] bullied us, it would take only a few months and we would get even." ${ }^{34}$

In reaction to these narratives, it could be argued that the army - especially the army after November 1989 - did not have enough training capacity or the financial resources to convert every soldier into a "marksman", and, moreover, that under the conditions of modern warfare between mass armies, shooting skills were no longer of crucial importance. Still, the contemporary witnesses stated in the interviews that they saw this as an important shortcoming. ${ }^{35}$ But, leaving the intensity of firearms training aside, the actors also considered familiarization with weapons and their effects as one of the few positive features of compulsory military service, and acquiring a respect for weapons was one of the most frequently used arguments for its potential reintroduction: "To be honest, then in a way, yes [reintroduction of the conscription], but not so that one would learn how to manage a gun, well, in fact yes, but in order to learn that

\footnotetext{
${ }^{33}$ Interview with D. K., conducted by Jiří Hlaváček, 16 April 2019. Rozhovory, DS COH ÚSD.

${ }^{34}$ Interview with P. V., conducted by Jiří Hlaváček, 4 July 2019. Rozhovory, DS COH ÚSD.

${ }^{35}$ On the other hand, the absence of training for real combat was caused to a certain extent by the increase in auxiliary services at the expense of combat services, which was one of the characteristic features of modern warfare. Since the early 20th century, it has therefore always been more common that a soldier experienced a war without engaging in direct combat. See HOLMES, Richard: Battle: The Experience of Modern Combat. In: TOWNSHEND, Charles (ed.): The Oxford History of Modern War. New York - Oxford, Oxford University Press 2000, pp. 224-244.
} 
it can do great harm and that, as the saying goes 'Words are like bullets. Once they are out, you can't control the damage they do.' And it is like that, I have seen what it can do (...) I saw a gunshot wound with my own eyes. And I saw that there was a target and behind it a block, and that the block had a hole in it. This is the force a weapon has (...) to make a lot of people realize that those weapons are dangerous." ${ }^{36}$

\section{Guard Duty in Peacetime}

Apart from shooting with live ammunition and military training, within their compulsory military service the soldiers could also hold a loaded gun when on guard duty. According to the norms of the period before 1989, guard duty was the only "truly combat task that can be fulfilled in peacetime". ${ }^{37}$ While on guard duty, the narrators found themselves in a specific situation. From a legal point of view, their status was untouchable, they had a firearm with live ammunition, had to know the regulations, were subordinated only to a limited number of people (regardless of the rank of anyone else with whom they would come into contact during their guard duty), and they had the responsibility of patrolling an entrusted compound or section. In case of intrusion, they were authorized to use the firearm after a prior warning; and arbitrary abandonment of the guard post was considered an offence. In this respect, the experience of being on guard duty was perceived by nearly all contemporary witnesses as a certain mental strain accompanied by fear. However, it also had an indirect positive effect on boosting their self-confidence: "The vehicle fleet was enclosed behind a double fence (...) and when you went on guard duty, it was for 24 hours and it was split so that they always took us for two hours between those wires, you got 60 live [rounds of ammunition] and you marched there. And you kept watch. And they told us - 'Don't be stupid, from time to time, somebody climbs over, wanting to pinch something, there is no ideology in it, somebody wants to steal there.' (...) And so they put me there, luckily it was not in the winter, and I really marched there for two hours in the night, I had a loaded submachine gun and thought to myself - if anyone comes, if he only tries, I will probably zap him. Because, I told myself - nobody asked me if I wanted to be here and if some bastard comes

\footnotetext{
${ }^{36}$ Interview with M. ST., conducted by Petr Wohlmuth, 8 September 2020. Rozhovory, DS COH ÚSD.

${ }^{37}$ NĚMEČEK, Zdeněk et al.: Základná vojenská príručka: Určené pre brancov a vojakov $v$ základnej službe. [Basic Military Handbook: Intended for Conscripts and Soldiers in Compulsory Military Service]. Praha, Naše vojsko 1986, p. 389.
} 
here to pinch something, laughing afterwards, yeah? It is simply a question, of course, it is always about the moment, what would you do, you know? So, I can't say for sure what I would or wouldn't do. (...) It is a bit you or me. So, this was an experience with a kind of extreme situation. Then, early in the morning (...) there were two in my zone, I don't know, a first lieutenant, a captain, and I told them - are they so stupid they can't see a soldier with a submachine gun and a fixed bayonet? And I say - 'please, do not come in here', against the regulations. And they - 'Come on, we are only going for...' And that's when I cocked the submachine gun and said - 'Stop, step back!' According to the regulations. They stopped - 'Okay, okay, we know, we are leaving now.' I saw what it could do. Only the fact of cocking that submachine gun (...) does an awful lot. (...) And nobody did anything to me, I chased off two officers." ${ }^{38}$

A strong emotional experience of guard duty can be considered an experience shared across generations. After the terrorist attacks in the United States of America at the beginning of the new millennium, the Czech conscripts also carried out mixed police and army patrols, patrolling objects and spaces of special significance during the US army invasion of Iraq in the Second Gulf War in the spring of 2003. However, the reflections of these guard duties - even though soldiers also had live ammunition during them - no longer have the character of a strong emotional experience or a sense of threat. In the recollection narratives, they rather build on a vast corpus of anecdotal stories on different ways of "killing" time during conscription.

Combat Vehicles and (Pseudo)Readiness

Another big theme of the interviews was combat vehicles. Before 1989, the Czechoslovak army had a great number of combat vehicles, and (regardless of the ongoing modernization of some types of weaponry and vehicles) the testimonies of contemporary witnesses of different generations provide an account of their gradual obsolescence. The specific vehicles were therefore not perceived negatively or pejoratively for their - mostly Soviet - origin or perhaps unreliability, but mainly for the poor technical condition they were in and because they showed substantial signs of wear and tear. ${ }^{39}$

\footnotetext{
${ }^{38}$ Interview with D. B., conducted by Jiří Hlaváček, 2 May 2019. Rozhovory, DS COH ÚSD.

${ }^{39}$ Along the Czechoslovak border in the 1980s, in terms of the quantity of conventional weapons the ČSLA exceeded the enemy allied forces several times, but their technical quality was in general lower and, over the years, it gradually decreased. However, the NATO armies had
} 
Whereas in the case of reflections from the late 1960s and early 1970s we come across narratives in which combat vehicles are assessed mostly (though not exclusively) positively, what is typical for those who did compulsory military service later (including the conscripts serving after 1989) is an increasingly negative evaluation, not only of the combat vehicles, but also of the conditions of their maintenance and storage. ${ }^{40}$ However, it is typical of the army that an order has to be carried out "at any price", and if it cannot be carried out with the expected result, then it has to be executed at least formally (that is, literally), which often led to absurd, even grotesque situations as was the case even in an elite special purpose unit in the following situation: "Back then the army did not work well, as there was a lack of everything, nothing worked, everything was old, damaged, everything was being painted, straightened all the time. Everything was hopelessly worn out. In the garages, there were the ZILs, the URALs [trucks produced by the Soviets] and these radio vehicles with all sorts of special superstructures. But the garages were built around the 1950s for the Czech Praga V3S and Tatra trucks, which were smaller and lower, so the Russian cars could not fit into the Czech garages, by some twenty centimetres. (...) Of course, there was no money for rebuilding (...) so the driver would back up to the garage entrance and let half the air out of tyres and then, on those half-deflated tyres when the car was lower, they slowly entered the garage on the tyre rims and once inside, they would inflate the tyres again. So, when a combat alert was sounded, it all started with the drivers deflating the tyres, and then there was, of course, a compressor to inflate them, well, when it worked. And it also happened that everybody ran around with huge tyre pumps, pumping the ZIL trucks. So, all the alert times were fucked up before the tyres could get pumped." ${ }^{\prime 1}$

This reflection leads us to the phenomenon of combat readiness and combat training alerts, which formed an integral part of the everyday life of most military units before 1989. In the case of combat readiness, this mainly involved the units deployed close to the state border with West Germany. According to

advantage in nuclear weapons. See TOMEK, P.: Československá armáda v čase sametové revoluce, pp. 13-14.

${ }^{40}$ This did not apply to the reflections of those conscripts who, after they had done their compulsory military service, decided to become professional soldiers or active reserves. Their view is, given that they had accepted the professional ethos, often less critical: "I think that the army always maintained combat effectiveness. Of course, there were some technical limits, I know, but even those - back then from my point of view, historical - combat vehicles were maintained in surprisingly good condition and definitely were useable." Interview with P. N., conducted by Jiří Hlaváček, 16 April 2019. Rozhovory, DS COH ÚSD.

${ }^{41}$ Interview with Z. N., conducted by Kateřina Niekurzáková, 4 January 2020. Rozhovory, DS COH ÚSD. 
regulations, the army was put on a state of combat readiness by a combat alert, during which all the units were to assemble within the time limit of ten minutes, leave the barracks with the combat vehicles within 30 to 40 minutes, move to the assembly point, and subsequently adopt positions at intervals of several kilometres, so that the enemy would cause only minimal losses to these units in case of a mass nuclear or chemical attack. ${ }^{42}$ However, according to the contemporary witnesses, the impact of these combat alerts to increase combat readiness was limited, because one of the (necessary) conditions to reach established limits was to be informed about them in advance. Thus, the conscripts usually slept fully dressed, with their boots on and all their gear prepared, ready to move. All the more unpleasant were the unannounced and hence really unexpected combat alerts, as the following excerpt illustrates: "When there was a combat alert, you knew eighty percent of the time that there would be an alert in the evening so you prepared for it. (...) Once, unfortunately, we did not know about it, so it was a classic, we left and had our camouflage suits on over our pyjamas, nothing in our backpacks, tea in our canteens and we left to go somewhere for a week: it was a complete fuck up. And it was in winter (...) but mostly, or always, you knew about it and they [the officers] were satisfied, because as they told us, we had time, it wasn't chaos." 43

\section{Conclusions on the Conflict between Official Discourse and Discourse Arising from Experiences}

If we focus on a purely quantitative approach to the collected oral history material, we can observe since 1968, through the frequency and character of connotations within the selected themes, a gradually growing distrust of the capacity of the Czechoslovak, and later also Czech, army to withstand the conditions of real combat. ${ }^{44}$

Whereas it is still possible to find reflections about modern technology and potential war as an equally balanced situation between the warring parties in the interviews with the conscripts from the late 1960s, as early as the 1970s, a number of narratives start accentuating a feeling of fatalism - the "one-minute soldiers" (referring to their life in combat) - or, eventually, emphasize the qualitative difference between various units ("it depends where you served") or even

\footnotetext{
${ }^{42}$ VALEŠ, J. - VESELÝ, M.: Základní řády, p. 112.

${ }^{43}$ Interview with R. G., conducted by Petr Wohlmuth, 3 September 2020. Rozhovory, DS COH ÚSD.

${ }^{44}$ Themes related to combat effectiveness tended to be evaluated more critically mainly by the university graduates within the research sample of narrators.
} 
directly point to the fact that the meaning of compulsory military service "lies elsewhere than in combat" (mainly on the level of socialization). The reflection of military service in the last decade of the communist regime in Czechoslovakia is marked by total disillusionment, nihilism and resignation. According to contemporary witnesses, the ČSLA was in "disintegration" at that time and in the event of conflict the soldiers would (as a result of conditions created by the unofficial disciplinary order - that is, the superiority of the more senior soldiers over the junior soldiers) first "shoot each other" and the survivors would subsequently "desert", with "only a third of combat vehicles actually leaving the barracks" and immediately "getting stuck" in the unknown terrain. ${ }^{45}$

The problem of the period after the Velvet Revolution does not lie so much in the unwillingness of the actors to do compulsory military service in the newly built democratic army. On the contrary, given the new possibility to opt for substitute civilian service, those who did enter the army were usually young men who did not expect any major problems with adapting to the conditions in the army. It was more a question of the open confrontation with the inertia of communist orders in combination with excessive efforts by the army to avoid drawing attention to its combat function (not provoking the public with any big and costly military manoeuvres) and general uncertainty regarding its future course. ${ }^{46}$ The witnesses therefore perceived their service in the army in the 1990s mainly on the level of rear support and "cleaners", who were "graciously" allowed by the professional soldiers to "shoot some rounds". The more imminent the professionalization of the army was, the more the conscripts were seen as a "burden" who "can't be taught anything substantial in a year" anyway and so "we had better not let them do anything".

Therefore, experience with weapons and respect for them can be considered the only positive aspect of compulsory military service with regard to preparation for combat that can be identified in the reflections of witnesses throughout the period explored. And this, together with the emotionally important experience of guard duty, contributed to the self-confidence of most actors, which also

${ }^{45}$ In this respect, the recollections of the narrators are almost identical with the reflections of the conscripts in the Soviet army during the same period. See, for example, COCKBURN, Andrew: The Threat: Inside the Soviet Military Machine. New York, Random House 1983, p. 44.

${ }^{46}$ As is stated by Hana Červinková, the problem of the Czech army after joining NATO in 1999 was chiefly related to its staff. The positions of senior officers were held by people who still had long-term experience with the socialist army. They usually lacked English skills and did not understand modern warfare or technologies and therefore had a problem with the process of "Ramboization" which the public expected from professional soldiers in the Western manner. See ČERVINKOVÁ, H.: Playing Soldiers in Bohemia, p. 28. 
manifests in other narrations closely related to the compulsory military service experience.

Nevertheless, the increasingly negative evaluation of combat readiness was not influenced only by the disillusionment of the actors regarding the military training and obsolete equipment, but also by the referential frameworks of the period in the form of social, political and international development, that is, the growing scepticism over the future course of socialism in Czechoslovakia and in other countries of the Eastern Bloc. In particular, it was the perception of the disproportion between the total time spent in military service (regardless of whether it was 12,18 or 24 months) and the amount of time dedicated to actual combat preparation. In this respect, the reflections of conscripts are in contradiction with the representations of combat readiness as reconstructed by former professional soldiers within similar oral history research works. This can be explained mainly by the absence of the professional military ethos in the case of most of the conscripts (with the exception of those who later voluntarily became professional soldiers or active reserve members). ${ }^{47}$

In general, what predominates in the recollections of actors is a rather negative image of the army as a more or less useless "total institution", which, up until the 1990s - undoubtedly mainly as a result of the August 1968 occupation - de facto had no social prestige. That is also why the majority of actors had problems identifying with its ethos (i.e. with its values and its mission). Their main aim therefore was merely to "survive" the period which they were forced to spend in the barracks, and this often had - given the existence of an elaborate, hereditary ritual, disciplinary order - a literal meaning. Due to an ambivalent experience with the duality of the disciplinary order, many contemporaries gradually concluded that the essence of "real" military service was not military training (the official order), but the individual way of coping with violent repression and with the violation of human dignity by more "senior" soldiers against

${ }^{47}$ See HLAVÁČEK, Jiří: Copak je to za vojáka... aneb Malá sonda do života př́íslušníků Československé (lidové) armády po roce 1968 [Who's That Soldier... or A Brief Insight into the Life of Members of the Czechoslovak (People's) Army after 1968]. In: VANĚK, Miroslav KRÁTKÁ, Lenka (eds.): Př́běhy (ne)obyčejných profesí: Česká společnost v období tzv. normalizace a transformace [The Stories of (Un)Common Professions: Czech Society During the Periods of the So-Called Normalization and Transformation]. Praha, Karolinum 2014, p. 73-120. Cf. RYGÁL, Florián: Veteráni studené války vzpomínají [Cold War Veterans Recall]. Praha, printed by the author 2012; VACEK, Miroslav: Generál studené války [A Cold War General]. Praha, Nakladatelství Erika 2004; ZACHARIÁŠ, Mojmír: Př́běh vojáka: Pohled na čtyřicetiletou službu vojáka z povolání, od poručíka po generálporučíka, od 50. let až po listopadovou revoluci 1989 a krátce po ní [A Soldier's Story: Looking Back at a Forty-Year Service as a Professional Soldier, from Lieutenant to Lieutenant General, from the 1950s to the Velvet Revolution in 1989 and Shortly Afterwards]. Praha, Dokořán 2012. 
"junior" ones, with superiority derived solely from the date of entering military service. In this context, it would undeniably be interesting to compare the largely negative experiences of the former Czechoslovak (or Czech) conscripts with the reflections of conscripts from other countries of the former Eastern Bloc. As the reflections of the witnesses indicate, the institution of compulsory military service has failed on most levels of meaning - levels that are crucial for the governing regime - that is at the functional (combat readiness), ideological (political consciousness) and power (subject to discipline) levels, whereas a positive impact can be observed only with respect to integration (socialization) and cultural (initiation) meanings.

Nostalgic (selective) recollections of military service in the form of anecdotes, which is also typical of the memoirs, must therefore be understood primarily as a sort of mental hygiene, which allows the contemporary witnesses to side-line the otherwise mundane, but often also traumatic, reality of their military service. ${ }^{48}$ The notion of compulsory military service as a mere obligation to be "fulfilled" then comes to the fore mainly in the case of witnesses from the ranks of university graduates whose perception of military service is often considerably more critical than that of others. Aspects of gender and masculinity represent inherent generational features of the recollections of military service. Like previous generations in the past centuries, the narrators too (un)consciously incorporate their individual stories into a broader framework of the dominantly masculine identity that is typical of the military environment and is also manifested, to a great extent, in the public discourse of the period, in which compulsory military service is seen as a confirmation and reproduction of a hierarchical patriarchal order.

This article is a result of the research funded by the Czech Science Foundation under the Contract No. 410/19-19311S (Army as an Instrument of Socialization: Reflection of the Phenomenon of Compulsory Military Service in the Czech Lands, 1968-2004).

\section{Abstract}

The article focuses on conscripts' reflections of compulsory military service in the Czechoslovak and Czech army in 1968-2004, as experienced by different generations. I pay attention mainly to the narrative representation of certain aspects

${ }^{48}$ See, for example, GRUBER, Petr: Dva roky základ'ákem anebo Jak to bylo doopravdy: ČSLA 1982-1984 [Two Years as a Conscript or What It Was Really Like]. Brno, Tribun EU 2012; VĚTříšEK, Lubomír: Dva roky v hajzlu [Two Years Down the Drain]. Brno, Host 2021. 
of the meaning of compulsory military service, namely the conscripts' preparedness for the defence of their country and actual deployment in combat. This is done through an analysis and interpretation of oral history interviews. On a practical level, I explore reflections of military exercises, the relation of contemporary witnesses to weapons and their potential use, evaluation of combat vehicles and effectiveness of combat alerts. In a theoretical perspective, the article is based on the cultural model of military history with an emphasis on confronting the discourse based on experience with the official model of compulsory military service, taking into account collectively shared ideas about the army. In general, what predominates in the recollections of actors is a rather negative image of the army as a more or less useless "total institution", which, up until the 1990s - undoubtedly mainly as a result of the August 1968 occupation - de facto had no social prestige. Due to an ambivalent experience with the duality of the disciplinary order, many contemporaries gradually concluded that the essence of "real" military service was not military training (the official order), but the individual way of coping with violent repression and with the violation of human dignity by more "senior" soldiers against "junior" ones.

Keywords:

Czechoslovakia; Czech Republic; state socialism; Czechoslovak army; Czech army; military history; compulsory military service; Czechoslovak normalization; oral history. 
